Vol. 2, No. 2, Seri B, Mei 2020, Hal 2726-2739

ISSN : 2656-3649 (Online)

http://jea.ppj.unp.ac.id/index.php/jea/issue/view/23

\title{
PENGARUH MANAGEMENT CHANGE, UKURAN PERUSAHAAN KLIEN, DAN AUDIT FEE TERHADAP AUDITOR SWITCHING
}

\author{
Vivi Aulia Najwa', Efrizal Syofyan ${ }^{2}$ \\ ${ }^{1}$ Alumni Juursan Akuntansi Fakultas Ekonomi Universitas Negeri Padang \\ ${ }^{2}$ Jurusan Akuntansi Fakultas Ekonomi Universitas Negeri Padang \\ *Korespondensi: vivinajwa98@gmail.com
}

\begin{abstract}
The purpose of this study was to analyze the effect of management change, client company size, audit fee on auditor switching. The data used in this study are annual and financial reports In manufacturing companies listed on the indonesia stock exchange (idx) in the period 2014-2018. The method of taking data samples using purposive sampling method. Based on certain criteria. Based on the retrieval method obtained A sample of 136 companies. Hypothesis testing in this study uses Logistic regression analysis. The results show that management change, company size has no effect on auditor switching and audit fees have a positive effect on auditor switching
\end{abstract}

Keywords: management change, client company size, audit fee, and auditor switching

How to cite (APA $6^{\text {th }}$ style):

Najwa, V. A \& Syofyan, E.. (2020). Pengaruh Management Change, Ukuran Perusahaan Klien, dan Audit Fee Terhadap Auditor Switching. Jurnal Eksplorasi Akuntansi. 2(2), Seri B, 2726-2739.

\section{PENDAHULUAN}

Perusahaan go public harus diaudit oleh KAP yang terdaftar di OJK dan perusahaan harus menyampaikan laporan keuangan yang disusun sesuai (SAK).Perusahaan yang menggunakan jasa akuntan publik wajib untuk melaksanakan auditor switching. Auditor switching ialah peraturan pergantian Kantor Akuntan Publik yang wajib dipatuhi suatu perusahaan untuk menjaga hasil kualitas audit dan mempertahankan independensi seorang auditor(Soraya,2017).

Di Indonesia, pergantian KAP dalam Peraturan Menteri Keuangan Republik Indonesia Nomor 17/PMK.01/2008 pasal 3 dijelaskan pemberian jasa audit umum untuk laporan keuangan dalam suatu entitas yang dimaksud dalam pasal 2 ayat 1a dilakukan oleh KAPpaling lama 6 buku berturut-turut, sedangkan untuk Akuntan publik hanya boleh memberikan jasa selama 3 tahun buku berturut- turut paling lama. Setelah 1 tahun buku tidak menerima jasa audit terhadap laporan keuangan perusahaan sebelum nya seorang akuntan public bisa menerima kembali jasa audit. Peraturan mengenai jasa akuntan publik diperbarui dengan dikeluarkan Peraturan Pemerintah No. 20 / 2015 tentang "Praktik Akuntan Publik" pasal 11 ayat (1) yang mengatur 
seorang akuntan publik dapat memberikan jasa audit terhadap informasi keuangan historis atas suatu perusahan dibatasi paling lama 5 (lima) tahun buku berturut turut dan akuntan public bisa memberi jasa audit kembali terhadap historis informasi laporan keuangan atas entitas yang dimaksud terdapat pada ayat 1 setelah 2 (dua) tahun buku berturut turut tidak memberi jasa audit.

Menurut Febrianto 2009, (dalam Wijayani, 2011) auditor switching bisa terjadi secara mandatory dan secara voluntary. Penyebab terjadi pergantian auditor secara voluntary dari sisi klien yaitu (misalnya manajemen gagal, kesulitan keuangan perusahaan, perubahan ownership ) sedangkan dari sisi auditor (misalnya kualitas audit, fee audit, dan lain sebagainya.Banyak pihak yang berpendapat jalan keluar dari masalah rendahnya independensi seorang auditor adalah auditor switching (Faradila dan Yahya, 2016). Di Indonesia belakangan ini terjadi kasus pergantian auditor oleh perusahaan PT. Inovisi Infracom Tbk. Akibat dari kasus yang terjadi pada perusahaan ini mendapat sanksi dari BEI yaitu pemberhentian sementara perdagangan saham karena ditemukan banyak terjadi kesalahan pada laporan keuangan perusahaan untuk kuartal III 2004.

Sebelumnya perusahaan ini diaudit oleh KAP Jamaludin, Ardi, Sukimto dan rekan. Setelah itu perusahaan investasi ini memilih Kreston International (Hendrawinata, Eddy Siddarta, Tanzil dan rekan) untuk mengaudit laporan keuangan perusahaan tersebut. Agar penyampaian laporan keuangan berkualitas dan sesuai dengan peraturan dan standar yang berlaku maka perusahaan harus melakukan auditor switching (www.detik.com, 2015). Dapat disimpulkan bahwa kasus yang terjadi pada PT. Inovisi Infracom Tbk yang sebelum nya sudah melakukan kesalahan terhadap laporan keuangan yang di audit oleh KAP sebelumnya malah mengganti auditor ke KAP yang jauh lebih besar. Pergantian KAP yang dilakukan oleh perusahaan bukan atas dasar peraturan tetapi karena perusahaan ingin penyajian laporan keuangan perseroan berkualitas dan terjadi peningkatan sesuai standar dan ketetapan yang berlaku.

Di Indonesia auditor switching sering dilaksanakan secara wajib (mandatory) akan tetapi fakta dan fenomena yang terjadi memperlihatkan bahwa perusahaan-perusahaan melakukan pergantian auditor secara sukarela (voluntary) (Pratitis, 2012). Audior switching secara sukarela dapat terjadi dikarenakan auditor mengundurkan diri atau dipecat oleh kliennya. Namun pergantian auditor dilakukan oleh klien, maka hal inilah yang akan membuat stakeholder merasa curiga serta munculnya pertanyaan masyarakat alasan perusahaan melaksanakan auditor switching secara sukarela karena fakta mengenai alasan perusahaan melakukan pergantian auditor tidak akan dicantumkan dalam laporan keuangan perusahaan. Maka dari itu fenomena pergantian auditor atau KAP sangat bagus dibahas,karena banyak faktor yang bisa berpengaruh pada keputusan perusahaan untuk mengganti auditor atau Kantor Akuntan Publik. Faktor-faktor penyebab dari permasalahan Auditor Switching yang akan diteliti yaitu Management Change, Ukuran Perusahaan, dan Audit Fee.

Pergantian manajemen pada suatu perusahaan dapat membawa terjadinya perubahan terhadap kebijakan pada bagian akuntansi atau keuangan dalam memilih kantor akuntan publik. Managament Change (pergantian manajemen) bisa sejalan dengan pergantian KAP karena KAP diminta agar mengikuti keinginan manajemen. Auditor Switching dapat terjadi dengan adanya pergantian manajemen karna adanya perubahan kebijakan yang terjadi.Ni Made Puspa Pawitri dan Ketut Yadnyana (2015). Ukuran perusahaan klien menunjukkan bahwa suatu skala agar mengklasifikasi kecil atau besarnya suatu perusahaan berhubungan pada keuangan perusahaan. Perusahaan yang kecil pada umumnya mempunyai masalah yang kecil, dan perusahaan yang besar umumnya memiliki masalah yang jauh lebih besar (Rasmini, 2013). 
Audit fee adalah suatu imbalan yang diterima oleh seorang auditor setelah memberikan jasa audit kepada kliennya. Audit fee (biaya audit eksternal) dapat diartikan sebagai besarnya imbalan jasa yang diterima oleh auditor eksternal yang akan melaksanakan pekerjaan audit. Imbalan jasa berhubungan dengan banyaknya waktu yang akan digunakan untuk menyelesaikan pekerjaan, nilai jasa yang diberikan kepada klien atau bagi kantor akuntan yang bersangkutan (Suhantiar, 2014). Menurut Fajrin (2015) mendefinisikan audit fee sebagai hak yang didapat oleh seorang auditor atas jasa yang sudah diberikan kepada kliennya. Menurut Mulyadi (2002 : 63) banyaknya fee anggota bisa bermacam-macam tergantung dari risiko penugasan, kerumitan jasa yang sudah dicurahkan, taraf keahlian yang dibutuhkan dalam melakukan jasa tersebut, besar biaya KAP yang bersangkutan dan melakukan pertimbangan professional lain. Anggota tidak diperbolehkan untuk menarik klien dengan taktik memberikan fee lebih besar atau bahkan lebih kecil dari ketetapan dan kualitas pekerjaannya yang dimana dapat mengurangi independesi seorang auditor.Pergantian auditor dapat dilakukan karena fee audit yang di tawarkan oleh suatu KAP jika terlalu tinggi terhadap suatu perusahaan sehingga tidak tercapainya kesepakatan antara perusahaan klien dengan KAP yang bersangkutan.

Tujuan penelitian ini untuk menganalisis pengaruh management change, ukuran perusahaan klien, audit fee terhadap auditor switching. Manfaatnya Bagi Penulis untuk menambah wawasan dan pengetahuan penulis tentang beberapa faktor yang berpengaruh pada (pergantian auditor). Bagi profesi Akuntan Publik dan Pemerintah, penelitianini diharapkandapat bermanfaat bagi para praktisi untuk dapat dijadikan informasi tambahan bagi profesi akuntan publik mengenai praktik auditor switching yang dilakukan perusahaan.Bagi pemerintah dapat dijadikan sumber bagi pemerintah mengenai praktek perpindahan KAP (auditor switching) oleh perusahaan.Bagi akademisi sebagai tambahan literature mengenai analisis keputusan perusahaan untuk mengganti KAP. Bagi peneliti lain sebagai referensi untuk penelitian yang sama dimasa akan datang.

\section{REVIU LITERATUR DAN PENGEMBANGAN HIPOTESIS Pergantian Auditor (Auditor Switching)}

Auditor switching ialah pertukaran auditor yang dilakukan oleh perusahaan. Pergantian auditor dilakukan secara mandatory dan juga secara voluntary.Pergantian auditor atau KAP dilakukan secara mandatory karena adanya ketetapan pemerintah yan mengharuskan dilakukannya auditor switching.Seperti yang terjadi di Indonesia dimana perusahaan wajib melakukan pergantian auditor sesuai dengan peraturan.Pergantian auditor atau KAP secara mandatory berlaku karena adanya peraturan pemerintah yang mewajibkan dilakukannya auditor switching yaitu paling lama 6 tahun berturut turut.Seperti yang terjadi di Indonesia dimana perusahaan wajib melakukan pergantian auditor sesuai peraturan mengganti akuntan publiknya ketika tidak ada peraturan yang diwajibkan mengganti akuntan publik (Susana dan Estralita, 2011).

\section{Teori Keagenan (Agency Theory)}

Hubungan agensi pada saat seseorang atau lebih (principal) memperkerjakan yang lain(agent) untuk memberikan jasa, setelah mendelegasikan wewenang pengambil keputusan terhadap agen tersebut. Pemicu adanya masalah agensi disini adalah perseteruan kepentingan antara principal dengan agent, yang berdampak tidak bertemu suatu tujuan yang sejalan antara mereka.Bukti teoritis pergantian auditor didasarkan kepada teori agensi. (Sulastriani da Sudarno, 2012:2).

Antara principal ataupun agent menginginkan keuntungan yang sebesar-besarnya dan ingin terlepas dari risiko yang bisa saja terjadi pada perusahaan. Didalam teori ini auditor 
independen berperan sebagai penengah antara dua pihak (principal dan agent) yang memiliki kepentingan yang berbeda. Disini auditor independen juga memiliki peran lain yaitu untuk mengurangi upah yang muncul dari perilaku manajer (agent) yang lebih mementingkan kepentingan pribadi. Dapat dilihat dimana managaement change dan ukuran perusahaan berpengaruh terhadap keputusan perusahan untuk mengganti auditor dan teori inilah yang digunakan sebagai dasar hipotesis pertama pada penelitian ini.

\section{Pergantian Manajemen (Management Change)}

Teori yang mempunyai kaitan dengan management change yaitu teori agensi yang dijelaskan oleh Anthony dan Govindarajan (2002), mengutarakan hubungan agensi ada pada saat salah satu pihak (pemegang saham) mengontrak pihak lain (manajemen) untuk melakukan suatu jasa agar bisa di percaya membuat suatu keputusan terhadap apa yang dilaksanakan manajamen (agent) tersebut. Terdapat adanya saling berkaitan antara klien dengan auditor nya yang memakai jasa auditor agar mengaudit laporan keuangan suatu perusahaan supaya relevan dan handal sehingga bisa menarik para investor, sedangkan seorang auditor harus professional jika mengaudit laporan keuangan kliennya dan mengeluarkan pengungkapan sesuai dengan keadaan perusahaan yang sebenarnya. Jika manajemen merasa auditor tidak bertugas dengan baik, maka disini manajemen berfikir untuk mengganti auditor suatu perusahaan.

\section{Ukuran Perusahaan}

Variabel ini memperlihatkan kecil besarnya perusahaan klien.Juliantari dan Resmini (2013) mendefinisikan bahwaa ukuran peusahaan klien merupakan skala yang mengklasifikasikan besar atau kecilnya suatu perusahaan tersebut yang berhubungan dengan keadaan financial suatu perusahaan. Menurut Sartono (2010:249) dalam Saldin (2016), perusahaan kecil akan lebih sulit memperoleh modal di pasar modal dibandingkan perusahaan besar. Maka dari itu perusahaan dengan kemudahan akses dan mempunyai fleksibilitas lebih besar adalah perusahaan besar.Utami (2015) mengatakan perusahaan besar lebih cenderung menggunakan KAP yang besar, yang dimana perushaan besar lebih memiliki masalah yang rumit dan kompleksitas usaha lebih luas dibandingkan perusahaan kecil. Pada umumnya penggunaan total aktiva, nilai pasar saham, nilai penjualan dan lain sebagainya bisa digunakan untuk mengukur besar atau kecilnya suatu perusahaan.

\section{Hubungan Antar Variabel \\ Management Change (Pergantian Manajemen) dengan Auditor Switching.}

Managament Change (Pergantian Manajamen) perusahaan terjadi apabila perubahan pada jajaran dewan direksinya . Damayati dan Sudarma (2007:9) mengemukakan pergantian direksi atas kemauan sendiri dapat terjadinya pergantian manajamen.Apabila terjadi perubahan pada kebijakan perusahaan menyebabkan terjadinya peruabahan dewan direksi, baik itu direktur ataupun komisaris. Setiap manajemen memiliki gaya kepemimpinan dan tujuannya masingmasing. Jadi, yang mendorong perusahaan agar mengganti auditor adalah pergantian manajemen yang terjadi secara langsung ataupun tidak langsung, karena manajemen akan segera mencari auditor yang sesuai dengan keinginan manajemen.

$\mathbf{H a}_{1}$ : Management Change (pergantian auditor) berpengaruh positif terhadap AuditorSwitching 


\section{Ukuran Perusahaan dengan Auditor Switching.}

Ukuran perusahaan klien dilihat dari adanya keadaan keuangan perusahaan yang dimana suatu skala dapat diklasifikasikan besar atau kecil nya suatu perusahaan.Perusahaan besar jauh lebih rumit dihadapi dibandingkan dengan perusahaan yang kecil (Mutchler, 1985).Untuk mengukur ukuran perusahaan dapat diproyeksikan pada total asset. Suparlan dan Andayani (2010) memperlihatkan dimana ukuran perusahaan klien mempunyai pengaruh positive terhadap pemilihan kantor akuntan publik. Berbanding terbalik dengan penelitian Chadegani, Mohamed, dan Jari (2011) menemukan dimana ukuran perusahaan berpengaruh negative pada pergantian auditor.

$\mathrm{Ha}_{2}$ : Ukuran perusahaan berpengaruh positif terhadap Auditor Switching

\section{Audit Fee dengan Auditor Switching}

Beberapa hal yang bisa memicu perusahaan untuk memutuskan untuk mengganti auditor penyebab nya ada pada audit fee yang ditawarkan auditor relative tinggi sehingga tidak terjadi kesepakatan kedua belah pihak mengenai besarnya audit fee dan itu menyebabkan perusahaan melakukan pergantian auditor (Schwartz dan Menon, 1985 dalam Astuti dan Ramantha, 2014).

Chadegani et all (2011) juga mengungkapkan bahwa ketika manajer merasa tidak sesuai dengan fee audit yang mereka inginkan, maka disini manajer mencoba untuk mengganti KAP dengan harapan manajer dapat memperoleh auditor yang sesuai dengan fee audit yang ditawarkan. Hasil dari penelitian Astuti dan Ramantha (2014) mengungkapkan Audit Fee berpengaruh signifikan pada pergantian auditor. Didukung oleh penelitian yang dilakukan oleh Utami (2015) mengungkapkan audit fee berpengaruh signifikan pada pergantian auditor. Oleh sebab itu, dapat disimpulkan hipotesa sebagai berikut :

Ha3: Perubahan audit fee berpengruh positif terhadap auditor switching

\section{METODE PENELITIAN}

\section{Metode Penelitian}

Jenis penelitian yang digunakan berdasarkan karakteristik masalahnya yaitu penelitian kausal komparatif (causal comparative research).Penelitian kausal komparatif merupakan tipe penelitian mengutarakan adanya hubungan sebab akibat antar dua variabel atau lebih, dimana variabel tersebut tidak dimanipulasi atau diberi perlakuan khusus oleh peneliti (Mudrajat Kuncoro, 2013).Data yang digunakan bersumber dari laporan keuangan dan tahunanperusahaan yang terdapat di Indonesia Stock Exchange (IDX) (www.idx.co.id).

Populasi dan sampel penelitian ini adalah perusahaan manufaktur Go Public yang terdaftar di Bursa Efek Indonesia (BEI) pada periode 2013sampai dengan 2018 yang sebanyak 136 perusahaan manufaktur yang terdaftar di BEI tahun 2013-2018. Pemilihan sampel dilakukan dengan menggunakan teknik purposive sampling yaitu teknik pengambilan sampel dengan pertimbangan atau kriteria tertentu, yaitu:

1. Perusahaan manufaktur yang terdaftar di BEI 2013-2018

2. Perusahaan manufaktur tersebut mempunyai laporan keuangan yang sudah diaudit serta dengan laporan yang sudah ditandatangani oleh auditor independen, dan laporan keuangan yang berisi data dan informasi lengkap.

3. Perusahaan manufaktur yang tidak menyajikan laporan keuangan dalam rupiah periode (20132018).

4. Perusahaan yang melakukan auditor switching secara mandatory. 


\section{Teknik Pengumpulan Data}

Variabel Dependen

Pengukuran variabel ini telah dilaksanakan oleh Prastiwi dan Wilsya (2009),52 dan Chadegani et al. (2011) untuk mengukur variabel ini menggunakan variabel dummy. Perusahaan yang mendapatkan nilai 1 masuk kedalam kategori auditor switching dan sedangkan perusahaan yang tidak melakukan auditor switching mendapatkan kategori nilai 0.

\section{Variabel Independen}

\section{Management Change}

Pengukuran variabel ini sebelumnya telah dilaksanakan oleh Chadegani et al. (2011) serta Damayanti dan Sudarma (2007).Variabel pergantian manajemen diukur menggunakan variabel dummy. Jika mendapatkan nilai 1 maka terjadi pergantian direksi, sedangkan apabila tidak terjadi pergantian direksi maka akan bernilai 0 .

\section{Ukuran Perusahaan}

Ukuran perusahaan dimana besar kecilnya suatu perusahaan dapat diukur melalui total aset nya. Perusahaan bisa dikatakan besar apabila semakin besar jumlah total aset perusahaan tersebut, begitupun sebalik nya perusahaan dikatakan kecil apabila semakin kecil jumlah total aset perusahaan tersebut. Pengukuran yang digunakan pada variabel ini yaitu dengan logaritma natural (Ln) terhadap total asset perusahaan. (Nasser et al., 2006:729)

\section{Ukuran perusahaan $=$ Ln total Asset}

\section{Audit Fee}

Audit Fee ialah besarnya biaya yang dibayar oleh perusahaan terhadap auditor untuk jasa mengaudit laporan keuangannya.Dalam penelitian ini data tentang audit fee akan diwakili oleh akun professional fees yang terdapat dalam laporan tahunan (annual report). Variabel audit fee akan diukur dengan menggunakan logaritma natural dari audit fee (Professional Fees). Logaritma natural digunakan untuk memperkecil perbedaan angka yang terlalu jauh dari data yang telah didapatkan sebagai sampel penelitian.

Audit Fee = Ln Audit Fee(Professional Fees)

\section{HASIL DAN PEMBAHASAN Statistik Deskriptif}

\section{Tabel 1}

Descriptive Statistics

\begin{tabular}{cccccc}
\hline & $\mathrm{N}$ & Minimum & Maximum & Mean & Std. Deviation \\
\hline Y_switch & 180 & .00 & 1.00 & .6111 & .48886 \\
\hline X1_CEO & 180 & .00 & 1.00 & .1111 & .31515 \\
\hline X2_TA & 180 & 25.62 & 31.34 & 28.2404 & 1.51905 \\
\hline X3_FEE & 180 & 18.60 & 25.83 & 21.7246 & 1.78988 \\
\hline
\end{tabular}

\section{Uji Kelayakan Model Regresi}

\section{a) Uji Horsmer and Lemeshow's Goodness of Fit}

Uji Horsmer and Lemeshow's Goodness of Fitdapat dilakukan untuk melakukanpengujian kelayakan model regresi logistik. Model bisa memperkirakan nilaiobservasinya dan bisa diungkapkan model diterima cocok oleh data oberservasinya jika nilai signifikansinya $>0,05$. Adapun hasil dari uji kelayakan model regresi sebagai berikut : 


\section{Tabel 2}

\section{Hosmer and Lemeshow Test}

\begin{tabular}{cccc}
\hline Step & Chi-square & Df & Sig. \\
\hline 1 & 18.300 & 8 & .019 \\
\hline
\end{tabular}

Dari hasil output diatas menunjukkan chi-square sebesar 18,3 dengan signifikansi 0,019. Nilai signifikansi diatas $<0,05$ sehingga model regresi pada penelitian tidak diterima atau kurang layak karena tidak sesuai data observasinya. Hal ini sejalan dengan nilai r square pada tabel 4.13 yang artinya masih banyak variabel lain memiliki pengaruh signifikan untuk varibel dependen pada penelitian ini.

\section{b)Uji Koefisien Determinasi (Nagelkerke's R Square)}

Untuk meyakinkan nilai memiliki variasi yaitu dari 0 hingga 1 maka Nagelkerke $R$ Square's ialah modifikasi dari koefisien Cox dan Snell. Untuk menunjukkan seberapa besar variabelitas variabel independen yang dapat dijelaskan variabelitas variabel dependen yaitu Nagelkerke's $R$ Square.

\begin{tabular}{|c|c|c|c|}
\hline \multicolumn{4}{|c|}{$\begin{array}{c}\text { Tabel } 3 \\
\text { Nagelkerke's } R \text { S q } \\
\text { Model Summary }\end{array}$} \\
\hline Step & $\begin{array}{c}-2 \log \\
\text { likelihood }\end{array}$ & $\begin{array}{c}\text { Cox \& Snell R } \\
\text { Square }\end{array}$ & Nagelkerke R Square \\
\hline 1 & $233.850^{\mathrm{a}}$ & .037 & .050 \\
\hline
\end{tabular}

Dari output Model Summary diatas bisa dilihat nilai dari Cox \& Snell $R$ Square sebesar 0,037. Sedangkan nilai Nagelkerke's $R$ Square sebesar 0,050. Hal ini memperlihatkan dimana variabel dependen yang bisa diterangkan variabilitas variabel independen ialah sebanyak $5 \%$ dan sisanya sebanyak 95\% dapat dijelaskan dengan variabel independen lainnya yang dapat mempengaruhi variabel dependen dari penelitian ini.

\section{c) Pengujian Multikolinieritas}

Uji multikolinearitas bertujuan agar mengetahui hubungan yang terjadi antara satu variabel independen dengan variabel independen lainnya. Untuk melihat besarnya korelasi antara variabel independen yang digunakan pada penelitian ini ialah matrik korelasi antara variabel bebas. Regresi yang tidak mempunyai gejala korelasi kuat diantara variabel bebasnya merupakan model regresi yang baik. Hasil pengujian ditampilkan dalam tabel 4 :

Tabel 4. Matrik Korelasi Correlation Matrix

\begin{tabular}{llrrrrr}
\hline \multicolumn{1}{c}{ Constant } & X1_CEO & X2_TA & X3_FEE \\
\hline \multirow{2}{*}{1} & Constant & 1.000 & .037 & -.744 & .163 \\
\cline { 2 - 7 } & X1_CEO & .037 & 1.000 & .057 & -.136 \\
\cline { 2 - 7 } & X2_TA & -.744 & .057 & 1.000 & -.780 \\
\cline { 2 - 6 } & X3_FEE & .163 & -.136 & -.780 & 1.000 \\
\hline
\end{tabular}

Sumber data : Data Sekunder yang diolah tahun 2020 
Hasil pengujian mengungkapkan tidak adanya nilai koefisien korelasi antara variabel yang $>0,9$ maka dapat disimpulkan tidak terdapat gejala multikolinieritas antara variabel bebas yang serius.

\section{d)Matrik Klasifikasi}

Matrik Klasifikasi memperlihatkan seberapa besar kuatnya perkiraan pada model regresi untuk memperkirakan terjadinya auditor switching. Pada tabel klasifikasi terdapat kolom yang berisi nilai prediksi dari variabel auditor switching apabila terjadinya auditor switching maka akan diberikan nilai 1 sedangkan apabila tidak terjadinya auditor switching maka akan diberikan nilai 0. Selain itu terdapat baris yang memperlihatkan nilai observasi yang sebenarnya pada variabel auditor switching.Adapun nilai dari uji klasifikasi dari model regresi sebagai berikut:

Tabel 5

Uji Klasifikasi

Classification Table ${ }^{\mathrm{a}}$

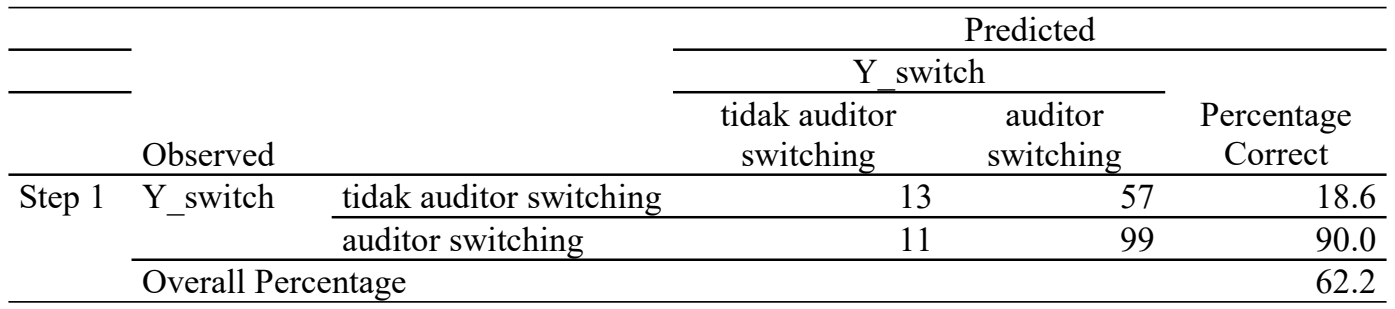

Sumber data : Data Sekunder yang diolah tahun 2020

Tabel 5 di atas memperlihatka dimana perusahaan akan melakukan auditor switching sebesar 90,0\% yang di perkirakan dari model regresi agar memperkirakan kemungkinan perusahaan untuk melakukannya. Artinya model regresi yang digunakan terdapat sebanyak 99 perusahaan (90,0\%) yang diperkirakan akan auditor switching dari total 110 periode perusahaan yang auditor switching. Sedangkan kekuatan prediksi model perusahaan yang tidak auditor switching yaitu sebesar 18,6\% yang berarti denga model yang dipakai terdapat 13 kali perusahaan $(18,6 \%)$ yang diperkirakan tidak auditor switching dari total 70 perusahaan. Secara keseluruhan ketepatan klasifiksi dalam penelitian ini sebesar $62,2 \%$.

\section{e) Analisis Koefisien Regresi}

Langkah berikutnya adalah melakukan analisis regresi logistik dan menguji koefisien regresi yang dihasilkan. Hasil analisis logistik yang didapatkan sebagai berikut:

\section{Tabel 6}

Hasil Uji Koefisien Regresi Logistik

\begin{tabular}{llrrrrrrr} 
& & \multicolumn{1}{c}{ B } & S.E. & Wald & Df & \multicolumn{1}{c}{ Sig. } & Exp(B) \\
\hline Step 1 $1^{\mathrm{a}}$ & & X1_CEO & -.214 & .496 & .187 & 1 & .666 & .807 \\
\cline { 2 - 9 } & X2_TA & -.290 & .164 & 3.118 & 1 & .077 & .748 \\
\cline { 2 - 9 } & X3_FEE & .361 & .146 & 6.134 & 1 & .013 & 1.435 \\
\cline { 2 - 9 } & Constant & .854 & 2.945 & .084 & 1 & .772 & 2.348 \\
\hline
\end{tabular}

Sumber data : Data Sekunder yang diolah tahun 2020 
Berdasarkan hasil analisis logistik diatas, maka diperoleh persamaan sebagai berikut:

$$
\text { SWITCH }=0,854-0,214 \mathrm{CEO}-0,290 \mathrm{LnTA}+0,361 \mathrm{LnFEE}+\mathrm{e}
$$

Adapun interpretasi dari nilai koefisien regresi logistik dalam persamaan diatas dapat dijelaskan sebagai berikut:

1. Konstanta senilai 0,854 menyatakan dimana akan terjadi perubahan sebesar 0,854 terhadap auditor switching jika diasumsikan management change, ukuran perusahaan, audit fee,mengalami perubahan (konstan).

2. Nilai koefisien regresi variabel management change(X1) sebesar -0,214. Hal ini memperlihatkan jika perusahaan melakukan management change maka keputusan dalam melakukan auditor switching akan menurun sebesar -0,214 dibandingkan dengan perusahaan yang tidak melakukan management change.

3. Nilai koefisien regresi variabel ukuran perusahaan (X2) sebesar -0,290. Hal ini menunjukkan setiap terjadinya kenaikan total asset pada ukuran perusahaan maka keputusan untuk melakukan auditor switching akan menurun sebesar -0,290 dengan asumsi variabel bebas lainnya dianggap konstan.

4. Nilai koefisien regresi variabel audit fee (X3) sebesar 0.361. Hal ini menunjukkan setiap terjadinya kenaikan fee audit maka terjadinya keputusan supaya melakukan auditor switching akan meningkat sebesar 0,361 dengan asumsi variabel bebas lainnya dianggap konstan.

\section{f) Pengujian Hipotesis}

Pengujian hipotesis yaitu uji yang digunakan untuk melihat ada atau tidaknya pengaruh dari management change, ukuran perusahaan, audit fee terhadap auditor switching untuk perusahaan manufaktur yang terdaftar di BEI untuk tahun 2014-2018. Berdasarkan output tabel 4.16, maka dapat diuraikan sebagai berikut :

\section{Pengaruh Management Change terhadap Auditor Switching}

Hipotesis pertama pada penelitian ini menyatakan dimana management change berpengaruh negatif terhadap auditor switching. Nilai koefisien regresi yang dihasilkan variabel management change sebesar $-0,241$ dengan signifikansi 0,666 . Pada tingat $\alpha=5 \%$, maka koefisien tersebut tidak signifikan karena nilai signifikansi $0,666>0,05$. Hal ini berarti management change tidak berpengaruh terhadap auditor switching. Berdasarkan hasil pengujian hipotesis diatas maka disimpulkan bahwa "H1 :Management Change berpengaruh negatif terhadap auditor switching"

\section{Pengaruh Ukuran Perusahaan terhadap Auditor Switching}

Hipotesis kedua menyatakan dimana ukuran perusahaanberpengaruh negatif terhadap auditor switching.Nilai koefisien regresi yang dihasilkan variabel ukuran perusahan sebesar -0,290 dengan signifikansi 0,077 . Pada tingat $\alpha=5 \%$, maka koefisien tersebut tidak signifikan karena nilai signifikansi $0,077>0,05$. Hal ini berarti ukuran perusahaan tidak berpengaruh terhadap auditor switching . Berdasarkan hasil pengujian hipotesis diatas maka disimpulkan bahwa "H2 : Ukuran Perusahaanberpengaruh negatif terhadap auditor switching” 


\section{Pengaruh Audit Fee terhadap Auditor Switching}

Hipotesis ketiga pada penelitian ini menyatakan dimana Audit Fee berpengaruh positif terhadap auditor switching. Nilai koefisien regresi yang dihasilkan variabel ukuran perusahan sebesar 0,361 dengan signifikansi 0,013 . Pada tingat $\alpha=5 \%$, maka koefisien tersebut tidak signifikan karena nilai signifikansi $0,013<0,05$. Hal ini berarti Audit Fee berpengaruh signifikan terhadap auditor switching. Berdasarkan hasil pengujian hipotesis diatas maka disimpulkan bahwa "H3 :Audit Fee berpengaruh positif terhadap auditor switching",

\section{PEMBAHASAN}

\section{Pengaruh Managament Change terhadap Auditor Switching}

Hasil uji hipotesis pada variabel Management Change memperlihatkan dimana Management Change tidak berpengaruh terhdap Auditor Switching pada perusahaan manufaktur dengan hasil negatif.Dengan demikian, hasil penelitian ini menolak hipotesis pertama (H1) yang menyatakan dimana management change tidak berpengaruh terhadap auditor switching. Ini memperlihatkan management change yang dilakukan pada perusahaan tidak terjadi dan tidak akan menimbulkan adanya perubahan kebijakan untuk auditor switching. Jadi jika terdapat management change pada perusahaan, tidak akan mendorong terjadinya auditor switching karena manajamen perusahaan tidak cenderung mencari auditor yang sesuai untuk kebijakan dan pelaporan akuntansinya.

Penelitian ini sesuai dengan penelitian Arezo, Zakiah dan Azam (2011), Rizkillah dan Didin (2012) dan Dwi dan Joicenda (2014), Damayanti dan Sudarma (2007), Sumadi (2012), Sinarwati (2011) yang menunjukkan bahwa variabel management change tidak berpengaruh terhadap auditor switching. Perlu adanya rasa waspada publik terhadap pihak manajamen apabila dalam memilih auditor yang baru, hal ini bisa disebabkan dimana manajamen cenderung memilih auditor yang memberi kebebasan pada pihak manajamen perusahaan agar bisa memilih prosedur akuntansi yang member keuntungan untuk manajamen itu sendiri.

Penelitian ini bertolak belakang dengan penelitian yang dilakukan Zadeh dan Rohi (2010), Wijayani dan Jamarti (2011), Wahyunngsih dan Suryanwa (2012), Sulitiarini dan Sudarno (2012), Adeng dan Adi (2012) yang memperlihatkan dimana variabel management change berpengaruh terhadap auditor switching. Kesimpulan dari pembahasan diatas yaitu management change tidak berpengaruh pada auditor switching.

\section{Pengaruh Ukuran Perusahaan terhadap Auditor Switching}

Hasil uji hipotesis ini memperlihatkan dimana variabel ukuranperusahaan tidak berpengaruh terhadap auditor switching pada perusahaan manufaktur dengan hasil negatif.Dengan itu, penelitian ini menolak hipotesis kedua (H2). Hasil negatif memperlihatkan dimana perusahaan yang besar cenderung tidak mengambil keputusan untuk auditor switching. Perusahaan besar mempunyai tingkat kompleksitas yang tinggi. Ini dapat dilihat dari data yang diamati oleh peneliti, perusahaan-perusahaan yang mempunyai nilai total asset yang besar tidak memilih untuk di audit oleh auditor atau KAP yang berafiliasi dengan the big four.

Hasil penelitian ini sesuai penelitian Varadita dan Mochammad (2012), Calderon dan Ofobike (2008), Chadegani et, al. (2011), Wijayani Juniarti (2011), Siska Aprianti dan Sri Hartaty (2016). yang menunjukkan bahwa ukuran perusahaan tidak berpengaruh pada Auditor Switching, namun tidak sejalan dengan hasil dari penelitian Adeng dan Adi (2012), dimana klien-klien yang mempunyai total aset kecil cenderung melakukan perpindahan KAP atau mengganti auditor yang tidak termasuk kedalam big four. Sedangkan perusahaan yang total asset 
nya besar tetap memilih KAP atau auditor big four untuk menjadi auditor nya yang sesuai dengan antara ukuran perusahaan dan ukuran KAP nya.

\section{Pengaruh Audit Fee terhadap Auditor Switching}

Hasil uji hipotesis ini memperlihatkan dimana variabel audit fee berpengaruh positif terhadap auditor switching pada perusahaan manufaktur. Dengan itu, penelitian ini menerima hipotesis ketiga (H3), yaitu audit fee berpengaruh positif pada auditor switching. Hasil positif memperlihatkan dimana fee audit tinggi memancing perusahaan agar cenderung mengganti auditornya. Damayanti dan Sudarma (2007) menjelaskan dimana pemilihan KAP atau auditor oleh perusahaan, yang diwakilkan oleh para pemegang saham, berhubungan dengan total fee yang akan mereka berikan. Rotasi pergantian auditor (auditor switching) yang sering mengakibatkan peningkatan untuk fee audit (Martina, 2010).

Dimana ketika auditor untuk pertama kali mengaudit 1 klien, yang paling awal sekali harus dilaksanakan oleh auditor yaitu memahami risiko audit perusahaan dan lingkungin bisnis suatu perusahaan tersebut. Untuk auditor yang tidak tau sama sekali dan tidak paham akan kedua masalah tersebut, maka untuk biaya start up akan menjadi lebih tinggi sehingga terjadilah kenaikan pada fee audit untuk perusahaan yang akan di audit tersebut. Penelitian ini berbanding lurus dengan penelitian Astuti dan Ramantha (2014), dan Utami (2015) yang dimana audit fee berpengaruh positif terhadap auditor switching.

Kesimpulan dari pembahasan diatas yaitu dimana audit fee berpengaruh positif terhadap auditor switching. Dimana ketika manajer merasa tidak sesuai dengan fee audit yang mereka inginkan, maka disini manajer mencoba untuk mengganti KAP dengan harapan manajer dapat memperoleh auditor yang sesuai dengan fee audit yang ditawarkan (Chadegani,et all 2011).

\section{KESIMPULAN, KETERBATASAN, DAN SARAN Kesimpulan}

Setelah melakukan analisis dengan menggunakan analisis regresilogistik maka dapat disimpulkan sebagai berikut :

1. Management change tidak berpengaruh terhadap auditor switching pada perusahaan manufaktur yang terdaftar di BEI untuk periode tahun 2014-2018.

2. Ukuran perusahaan tidak berpengaruh terhadap auditor switching pada perusahaan manufaktur yang terdaftar di BEI untuk periode tahun 2014-2018.

3. Audit fee berpengaruh positif terhadap auditor switching pada perusahaan manufaktur yang terdaftar di BEI untuk periode tahun 2014-2018.

\section{Keterbatasan}

1. Dapat dilihat dari hasil pengujian Nagelkerke's $R$ Square dimana menyatakan didalam output model summary, diketahui nilai Nagelkerke's $R$ Square yaitu sebesar 0,050 yang dimana variabel dependen yang bisa diterangkan oleh variabel independen hanya sebesar 5\% sedangkan sisanya adalah $95 \%$ yang dapat diterangkan oleh variabel lain yang tidak bisa diungkapkan didalam penelitian ini antara lain ialah opini audit, financial distress, $u$ kuran KAP, audit tenure, reputasi auditor, audit delay, kualitas audit, dan masih banyak lagi sehingga dapat dijelaskan bahwa pengaruh yang diberikan oleh ke-tiga variabel independen pada penelitian ini belum dapat mempengaruhi secara menyeluruh variabel dependen pada penelitian ini. 
2. Penelitian ini hanya dilakukan untuk satu sektor saja yaitu manufaktur sehingga hasil penelitian ini belum bisa digeneralisasikan untuk semua perusahaan yang terdaftar di Bursa Efek Indonesia (BEI).

\section{Saran}

Adapun saran-saran yang bisa disampaikan sehingga untuk penelitian selanjutnya bisa mendapatkan hasil yang jauh lebih baik, antara lain :

1. Bagi Perusahaan

Diharapkan perusahaan agar memperhatikan faktor-faktor yang dapat mempengaruhi auditor switching agar dapat menghasilkan kualitas hasil audit yang baik. Seperti audit fee yang pengukuran nya di ukur berdasarkan jumlah fee audit yang diberikan oleh perusahaan kepada auditor sehingga dapat menghasilkan kualitas audit yang baik. Dimana ketika auditor untuk pertama kali mengaudit 1 klien, yang paling awal sekali harus dilaksanakan oleh auditor yaitu memahami risiko audit perusahaan dan lingkungin bisnis suatu perusahaan tersebut. Untuk auditor yang tidak tau sama sekali dan tidak paham akan kedua masalah tersebut, maka untuk biaya start up akan menjadi lebih tinggi sehingga terjadilah kenaikan pada fee audit untuk perusahaan yang akan di audit tersebut.

2. Bagi penelitian selanjutnya

a. Untuk penelitian selanjutnya diharapkan agar menambahkan beberapa variabel lainnya yang di prediksi dapat berpengaruh terhadap auditor switching baik itu faktor eksternal ataupun faktor internal. Dan

b. Untuk penelitian selanjutnya agar dapat memperluas objek penelitian sehingga bisa mengeneralisikan penelitiannya.

\section{DAFTAR PUSTAKA}

Adeng Pelu dan Adi Kuswanto.(2012). "FaktorFaktor yang Mepengaruhi Auditor Swit ching pada Bank yang Tercatat di BEI". Universitas Gunadarma.

Aprianti, Siska., Sri Hartaty. (2016). Pengaruh Ukuran KAP, Ukuran Perusahaan Klien, dan Tingkat Pertumbuhan Perusahaan Klien Terhadap Auditor Switching. Jurnal Akuntansi Politeknik Sekayu (ACSY). Volume IV. No.1.

Ardiani, Wiwik. 2017. Faktor - Faktor yang Mempengaruhi Auditor Switching:Studi pada Perusahaan Manufaktur yang Terdaftar di Bursa Efek IndonesiaPeriode Tahun 20132015. Skipsi Universitas Stikubank Semarang.

Agiastuti, I. P., \& Suputra, I. G. (2016). Faktor-Faktor yang Berpengaruh pada Voluntary Auditor Switching. E-Jurnal Universitas Udayana Vol.17.1, 56- 83.

Chadegani, A.A., Z.M. Mohamed, dan A. Jari. 2011. "The Determinant Factors of Auditor Switch among Companies Listed on Tehran Stock Exchange". International Research Journal of Finance and Economics, Issue 80, h. 158-168

Damayanti, S. dan M. Sudarma. 2007. "Faktor-Faktor yang Mempengaruhi Perusahaan Berpindah Kantor Akuntan Publik". Simposium Nasional Akuntansi 11, Pontianak.

Dwiyanti, R. M. E., \& A. Sabeni. 2014. Faktor-Faktor yang Mempengaruhi Auditor Switching Secara Voluntary. Diponegoro Journal of Accounting 3 (3).

Faradila,Yuka, dan M Rizal Yahya. 2016. Pengaruh Opini Audit, FinancialDistress, Dan Pertumbuhan Perusahaan Klien Terhadap Auditor Switching(Studi Pada Perusahaan Manufaktur Yang Terdaftar Di Bursa EfekIndonesia Tahun 2010-2014). 
Ghozali, Imam. 2013. Aplikasi Analisis Multivariate dengan Program IBM SPSS 21. Universitas Diponegoro: Semarang. . 2016. Aplikasi Analisis Multivariat dengan Program IBM SPSS 25. Edisi 8. Semarang: Badan Penerbit Universitas Diponogoro.

http://www.detik.com http://www.idx.co.id (Diakses bulan November 2019)

Hartono, A. T., \& Abdul, R. 2015. Analisis Hubungan Auditor-Klien : Faktor-Faktor yang Mempengaruhi Auditor Switching Di Indonesia. Diponegoro Journal of Accounting, 4(4): $1-12$.

I Wayan Ramantha, Ni Luh Putu Paramita Novi Astuti. 2014. Pengaruh Audit Fee, Opini Going Concern, Financial Distress, dan Ukuran Perusahaan pada Pergantian Auditor. E-Jurnal Akuntansi Universitas Udayana. Vol 7. No 3.

I.D.G. Dharma Suputra, Made Aditya Bayu Pradhana. 2015. Pengaruh Audit Fee, Opini Going Concern, Financial Distress, dan Ukuran Perusahaan pada Pergantian Auditor. E-Jurnal Akuntansi Universitas Udayana. Vol 11. No 3.

Juliantari, Ni Wayan Ari dan Rasmini, Ni Ketut. 2013. Auditor Switching dan Faktor- factor yang Mempengaruhinya E-Jurnal Akuntansi Universitas Udayana. Vol. 3, No. 3, hal. 231-246

Ketut Yadnyana, Ni Made Puspa Pawitri. 2015. Pengaruh Audit Delay, Opini Audit, Reputasi Auditor dan Pergantian Manajamen pada Voluntary Auditor Switching. E-jurnal Akuntansi Universitas Udayana

Menteri Keuangan. 2003. Keputusan Menteri Keuangan Nomor359/KMK.06/2003 tentang "Jasa Akuntan Publik": Jakarta.

Menteri Keuangan. 2008. Peraturan Menteri Keuangan Republik IndonesiaNomor 17/PMK.01/2008 pasal 3 tentang “Jasa Akuntan Publik": Jakarta.

Mulyadi. 2002. Auditing. Edisi keenam. Jakarta: Salemba Empat.

Mulyadi. 2014. Auditing 1. 6thed. Jakarta: Salemba Empat

Nabila. 2011. "Faktor-Faktor Yang Mempengaruhi Auditor Switching (StudiEmpiris Pada Perusahaan Manufaktur Di Bursa Efek Indonesia)". Skripsi Fakultas Ekonomi Universitas Diponegoro, Semarang.

Nasser, et. Al. 2006. "Auditor - Client Relationship : The Cose ofAudit Tenure and Auditor Switching In Malaysia”. Managerial Auditor Journal, val. 21, No. 7, PP. 724-737.

Peraturan Pemerintah Republik Indonesia No.20 tahun 2015 Tentang Praktik Akuntan Publik.

Pratitis. (2012) "Auditor Switching" Analisis Berdasarkan Ukuran KAP Ukuran Klien,Dan Financial Disstress"

Rizkilah, dan Didin Mukodim. (2012). "FaktorFaktor Yang Berpengaruh Terhadap Audi tor Switching Pada Perusahaan Perbankan di Indonesia." Jurusan Akuntansi, Univer sitas Gunadarma.

Sari, Feby Fitria dan Abriyanti Purpaningsih. 2018. Pengaruh Opini Audit, Financial Distress, Perubahan ROA dan Pertumbuhan Perusahaan Klien terhadap Auditor Switching di Indonesia. Simposium Nasional Akuntansi XX.

Sinarwati, N. 2010. "Mengapa Perusahaan Manufaktur yang Terdaftar di BEI Melakukan Pergantian Kantor Akuntan Publik?”. Simposium Nasional Akuntansi 13, Purwokerto

Soraya, Ella dan Musfiari Haridhi.2017.Faktor-Faktor Yang Mempengaruhi Auditor Switching (Studi Empiris pada Perusahaan Non Financing yang Terdaftar di Bursa Efek Indonesia 
tahun 2011-2015. Jurnal Ilmiah Mahasiswa Ekonomi Akuntansi(JIMEKA).Vol.2,No.1, Hal.48-62

Sugiyono. 2014. Metode Penelitian Kuantitatif, Kualitatif dan R\&D. Cetakan Ke-7. Bandung: Alfabeta.

Suhantinar, Tiara Novriany danAgung Juliarto. 2014. "Pengaruh Konvergensi IFRS danClient Attributes Terhadap Penetapan Biaya Audit Eksternal”. Diponegoro Journal Of AccountingVolume 3, Nomor 4, Tahun 2014, Halaman 1-9.

Sulistiarini, Endina, dan Sudarno. 2012. "Analisis Faktor-Faktor Pergantian Kantor Akuntan Publik (Studi Empiris Pada Perusahaan Manufaktur di Bursa Efek Indonesia Periode 2006-2010)". Diponegoro Journal Of Accounting, vol. 1 No.2.

Sumadi, Kadek. "Mengapa Perusahaaan Melakukan Auditor Switch?" http://puslit.petra.ac.id/journals/accounting/diakses 12 Oktober 2012

Suparlan, dsan W. Andayani. 2010. "Analisis Empiris Pergantian Kantor Akuntan Publik Setelah Ada Kewajiban Rotasi Audit”. Simposium Nasional Akuntansi 13, Purwokerto.

Susan, dan Estralita Trisnawati. 2011. "Faktor-Faktor Yang Mempengaruhi Perusahaan Melakukan Auditor Switch”. Jurnal Bisnis dan Akuntansi, Vol. 13, No. 2, Hal 131-144.

Utami, Syilvi Fajria. 2015. Analisis Faktor- Faktor yang Mempengaruhi Perusahaan Melakukan Auditor Switching . Jurnal Bisnis dan Akuntansi Vol. 13. No.2, hal 131-144

Varadita Febriana dan Mochammad Didik Ardiyanto.(2012). "Faktor-Faktor yang Mempengaruhi Pergantian Kantor Akuntan Publik di Perusahaan Go Publik yang Ter daftar di BEI”. Disertasi. Fakultas Ekono mika dan Bisnis, Universitas Diponegoro.

Wahyuningsih dan Suryanawa. 2012. Analisis Pengaruh Opini Audit Going Concern dan Pergantian Manajemen Pada Auditor Switching. Jurnal Ilmiah Akuntansi dan Bisnis. Vol. 7 No. 1 Januari 2012.

Wibowo (2012). Manajemen Kinerja. Jakarta: raja Grafindo Persada.

Wijayani, E.D. dan Januarti, Indira. 2011. "Analisis Faktor - faktor yang mempengaruhi perusahaan di Indonesia melakukan Auditor Switching”. SNA XIV 2011. Aceh.

Wijayanti, Martina Putri, (2010). "Analisis Hubungan Auditor-Klien : Faktorfaktor yang Mempengaruhi Auditor Switching di Indonesia”. Skripsi, Jurusan Akuntansi Fakultas Ekonomi Universitas Diponegoro : Semarang.

Zadeh Peyman Iman and Ali Roohi, "Studying the Reasons of Auditor Change in Accepted Companies in Tehran Stock Exchange”, World Applied Sciences Journal 9, pg 734-739, 2010. 